\title{
Globeville: the neighborhood that shapes the learning environment for BFLA Spanish-English Mexican Americans
}

\author{
Irdawati Bay Nalls
}

Received: 27 August 2019 / Accepted: 18 March 2020 / Published online: 03 April 2020

(C) The Author(s). 2020 Open Access This article is licensed under a Creative Commons Attribution 4.0 International License, which permits use, sharing, adaptation, distribution and reproduction in any medium or format, as long as you give appropriate credit to the original author(s) and the source, provide a link to the Creative Commons licence, and indicate if changes were made. The images or other third party material in this article are included in the article's Creative Commons licence, unless indicated otherwise in a credit line to the material. If material is not included in the article's Creative Commons licence and your intended use is not permitted by statutory regulation or exceeds the permitted use, you will need to obtain permission directly from the copyright holder. To view a copy of this licence, visit http://creativecommons.org/licenses/by/4.0/.

\begin{abstract}
Bronfenbrenner's bioecological model is a theory of educational psychology that studies human development over time. Drawing on Bronfenbrenner's early theory on ecological systems, this paper focuses on the Mesosystem and Exosystem - environments in which Bilingual First Language Acquisition (BFLA) Spanish-English Mexican American children develop. It can also be regarded as a research on the immigrant community, as this paper looks at BFLA Spanish-English Mexican American bilinguals at an elementary school in Denver Public Schools (DPS), Colorado. As a marginalized immigrant community in America, their voices tell a story of their struggles, as they acculturate in America through their attempt to blend heritage, societal languages, and cultural practices. Globeville, a neighborhood located in North Denver, is home to many BFLA Spanish-English Mexican Americans. It shapes their growth, repositioning, and struggles as they learn to assimilate and acculturate in order to be accepted. Using historiography as a methodology, Globeville became the data itself, presenting a different kind of learning environment that promotes growth despite the odds.
\end{abstract}

Keywords Globeville · Mexican-American immigrants · Ecology of human development $\cdot$ Identity $\cdot$ Repositioning

I.B. Nalls $(\square)$

Department of Humanities and Social Sciences, Nanyang Technological University, 48 Nanyang Avenue, HSS-03-25, Singapore 639818, Singapore

e-mail: cookies264@yahoo.com 
Based on the 2010 Census, Mexican American bilinguals, who are a subset of the Mexican American populations in the United States (US), are the largest minority group in the country, and this number is rising (Orfield and Lee 2005). Recent statistics collected by the National Center for Education Statistics (2016) revealed that the projected demographic of minority groups, Mexican Americans included, will constitute $40 \%$ of the school-age population by 2025 . It is also estimated that by 2040, (monolingual) White Americans will make up less than $50 \%$ of the American population (Census 2010). Given the existing and projected population demographics, it is crucial to take into account the linguistic needs of Mexican American bilinguals as well as White Americans while planning educational programs in the US.

This research was conducted during the period from the end of 2014 to 2016 as part of a larger qualitative study that adopted a phenomenological approach (Creswell 2013), looking at the lived experiences of twelve immigrant children who are also Bilingual First Language Acquisition (BFLA) Spanish-English Mexican American. An urban elementary school in a low-income neighborhood in Denver, Colorado was selected as the main site for data collection. The neighborhood, Globeville, played a significant role in situating and repositioning the twelve BFLA Spanish-English Mexican American bilinguals. Bronfenbrenner.U (1979) argues that setting plays a key role in telling the story of language acquisition among children. The research question under investigation is, how does the community and neighborhood, Globeville, through its geographical location, contribute to the learning development, or lack thereof, of a marginalized group of BFLA Spanish-English Mexican American bilinguals? Below, I reveal how Globeville and its immigrant population promoted the development of their marginalized community.

It is important to note that the author was working with a population that is marginalized not only as a group of lower socio-economic income, but also as a racial minority group. On top of the group's marginalization, the student-participants were also bilinguals, which again raised doubts as to their linguistic ability to succeed in school, given the normalization of monolingual English in the US (Demont-Heinrich 2007; Fisher-Ari et al. 2017; Shannon 1995). The negative labels that have been used to identify the student-participants include English Language Learners (ELL), English Language Acquisition (ELA), language minorities, and failures at school (Cummins and Danesi 1990; Shannon 1995). The existence of these pejorative labels makes it vital for us to uncover the bilingual voices of students who are usually overlooked in education, and whose strengths and assets are often masked by quantitative assessments of their language and literacy abilities. The author argues that despite living in an industrial neighborhood, the people of Globeville as a community have evolved against the odds into a different kind of immigrant community, one with the potential to improve their situation by repositioning BFLA Spanish-English Mexican American bilinguals and recognizing them as assets. 


\section{Theoretical frameworks}

Bronfenbrenner.U (1979) defines the central process within the broad ecology of human development as "the progressive, mutual accommodation between an active, growing human being and the changing properties of the immediate setting(s) in which the developing person lives". With this understanding, the critical aspects of human development are both physical and social from a developmental perspective. These two aspects - the physical and the social - are what enable and encourage a child to participate in a variety of activities with an adult, with their peers, or spontaneously by themselves (Bronfenbrenner.U 1979). Following Bronfenbrenner, Globeville becomes a pertinent setting for a study that aims to reposition Bilingual First Language Acquisition (BFLA) Mexican American bilingual children.

Bronfenbrenner.U (1979) highlights ways in which children develop by observing their behaviors in natural settings. Although Bronfenbrenner did not adopt a critical lens, ignoring factors such as race, gender, and socioeconomic status, his work still inspires me to consider the natural environments in which Bilingual First Language Acquisition (BFLA) Spanish-English Mexican American bilinguals are immersed, specifically during their years of Spanish and English language acquisition in predominantly English-only environments. In the larger qualitative dissertation study of which the present paper comprises a part, I applied Bronfenbrenner's ecological theory as I looked at the language use and language choice of BFLA Spanish-English Mexican American children by observing them in their natural settings: their school and homes in Globeville. The fact that these students are bilinguals developing their linguistic skills of listening, speaking, reading, and writing (Brown 2007) in a monolingual society is a key consideration in my observations and analyses of their developing literacy skills. Bronfenbrenner's ecological theory formed the basis of my analyses, where I discuss how Globeville contributed to the students' development or lack thereof. Within said analyses, I emphasize the importance of the historiography of Globeville, the neighborhood in which the twelve student-participants lived and studied. Bronfenbrenner.U (1979) asserts that development takes place in interactive social environments (systems) such as the family, the preschool, or the classroom, referred to as microsystems. The interactions between these microsystems are referred to as mesosystems. When these mesosystems are linked and mutually supportive, it has been found to benefit the developing individual.

The diagram below summarizes how a child's language acquisition is impacted by their surroundings. Some describe this as a bottom-up approach, beginning with the student-participant, then their family, and continuing as their language usage is spread progressively further through community interactions, and later influenced by policies imposed upon society through schools. Others view this as a top-down approach, beginning with language policies and ending with the child. I conclude that childhood language acquisition is influenced in both directions, bottom-up and top-down. In my study, I looked at the impact of community on language acquisition, focusing on the neighborhood and residents of Globeville who are mostly lower income Mexican American families of immigrant descent. 


\section{Two-pronged approach: Language Acquisition and Impact}

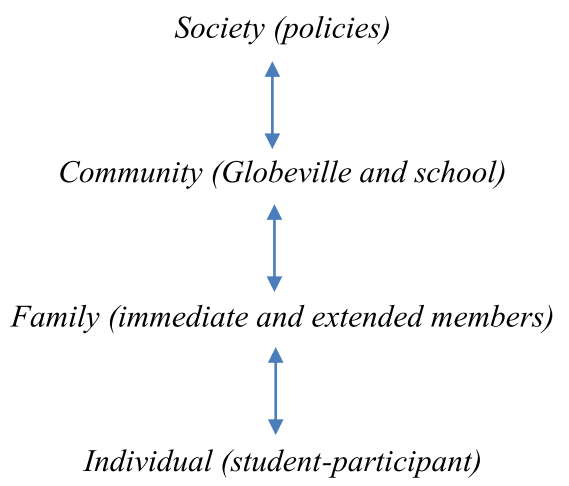

A child's language acquisition is impacted by his/her surroundings as much as the linguistic environment is impacted by the child's experiences with language acquisition. Mexican American parents, for example, are picking up English as their children attend American public schools. Community activities are changing in Globeville to accommodate the changing demographic of emerging bilinguals. Finally, policies are changing to try to better meet the learning needs of bilinguals. This can be seen in the frequent changes made to the bilingual policies in the US. Likewise, a Mexican American bilingual child is affected by the language choice of their immediate family members at social gatherings. In Globeville, the community determines the trade language used around the neighborhood. Finally, wider society, i.e. Americans, defines the language choice and preference that a Mexican American bilingual child may choose to develop over time.

This article firstly describes Globeville, its location, and how it is marginalized in terms of access to resources such as fresh foods and a proper public library. It goes on by looking at the residents of Globeville, past and present, and the reasons that brought them to live in Globeville. With a focus on the current population, mostly Mexican Americans, the article will highlight some of the challenges that these residents face in Globeville.

\section{Methods}

The study will illustrate the various meanings behind a social issue, namely the marginalization of an immigrant community of Spanish-English Mexican American bilinguals living in Globeville. In this study, data collection began within the focus participants' natural settings, the field sites at which participants experienced challenges when they were assimilating into the American society (Creswell 2013). I became the key instrument for data collection wherein I examined documents, observed behaviors, and interviewed the student-participants as part of a larger study (Creswell 2013). The present paper, therefore, is an analysis of the information 
gathered as part of said larger study, which looked at how use of language by an immigrant population impacted their status within a society (Nalls 2019).

Sites, participants, and data collection

Globeville was chosen as the main site of study due to its controversial status for the high volume of immigrants housed there. It is located in Denver, Colorado. I was interested in Mexican American bilinguals; the recent immigrants who form the largest immigrant population in the US (Census 2010). Methods of data collection for this historiography consisted of: visiting an elementary school in the neighborhood daily, visiting some homes of the immigrants living in Globeville, and taking part in an American cultural festival to better understand the immigrant community in Globeville. However, since this is a historiography, most of the data comes from secondary sources. This historiography, a result of data discovered through ${ }^{1}$ critical incident (Flanagan 1954), is crucial in telling the counternarratives of this unique immigrant population in the heart of Denver.

The qualitative research study involved long hours of participation observations in the student participants' natural communicative settings, where Spanish-English bilingualism was likely to occur. Bilingualism was the initial focus; however, through critical incidence methodology (Flanagan 1954), I discovered that the student-participants who were children of immigrants had so much more to tell in terms of bilingualism. As a result of this discovery, I ventured into their physical setting, beyond the four walls of the classroom, and documented their counternarratives throughout Globeville. Data was collected over a period of one semester, fall 2014, observing Bronfenbrenner.U (1979) suggestion that the best ways to understand children's development is to observe them in their natural settings.

To ensure that social, cultural, and political factors are considered in my analysis, I worked with BFLA Spanish-English Mexican Americans from various age groups, and from both gender norms. Initially, I did consider socio-economic status (SES) in my study, and attempted to look at BFLA Spanish-English Mexican American children from different SES groups. Ultimately, however, all of the student-participants came from similar SES backgrounds.

Since this qualitative study adopts a critical theory perspective, I am concerned with empowering human beings to transcend the constraints placed on them by race, class, and gender (Fay 1987). However, since this is a historiography of Globeville, other forms of data such as documents and artifacts looking at geographical location were also considered as part of the data collection and analysis process.

I have employed the practice of using a social justice interpretive framework (Creswell 2013) because, as I continually remind myself, the initial aim of this research is to help me better understand Colorado's BFLA Spanish-English Mexican American bilinguals during their elementary school years. Their positionality in terms of their social standing within the society, (social hierarchy), hegemony,

\footnotetext{
${ }^{1}$ Critical incidents is used to collect direct observations of human behavior that has critical significant. These observations can be used to solve problems.
} 
racism, unequal power relations, and identity were some of the factors that I considered as I observed them.

\section{Results: historiography of Globeville}

Globeville is a mixed residential-industrial neighborhood in Denver, Colorado. It is situated in North Denver, along the Platte River. It is bisected in two directions by major highways, I-25 and I-70, cutting the neighborhood into four parts. Currently, the residential community is surrounded by numerous industries. These industries include asphalt manufacturers, a wood treatment facility, a pet-food manufacturer, a stock complex, animal rendering facilities, an industrial plant, two smelters, and wastewater treatment facilities. The presence of the various industrial facilities in Globeville is not surprising given the town's geographical history.

Below are two images. The first is a simplified map of Globeville which shows its location in Denver. The second is an image showing Globeville as an industrial community in Downtown Denver (Figs. 1 and 2).

Globeville was originally occupied by homesteaders and farmers. The area was well-known for the smelters that were built before the turn of the twentieth century and for the Eastern European immigrants who worked in the area. These settlers came to Globeville to seek religious freedom and economic opportunities.

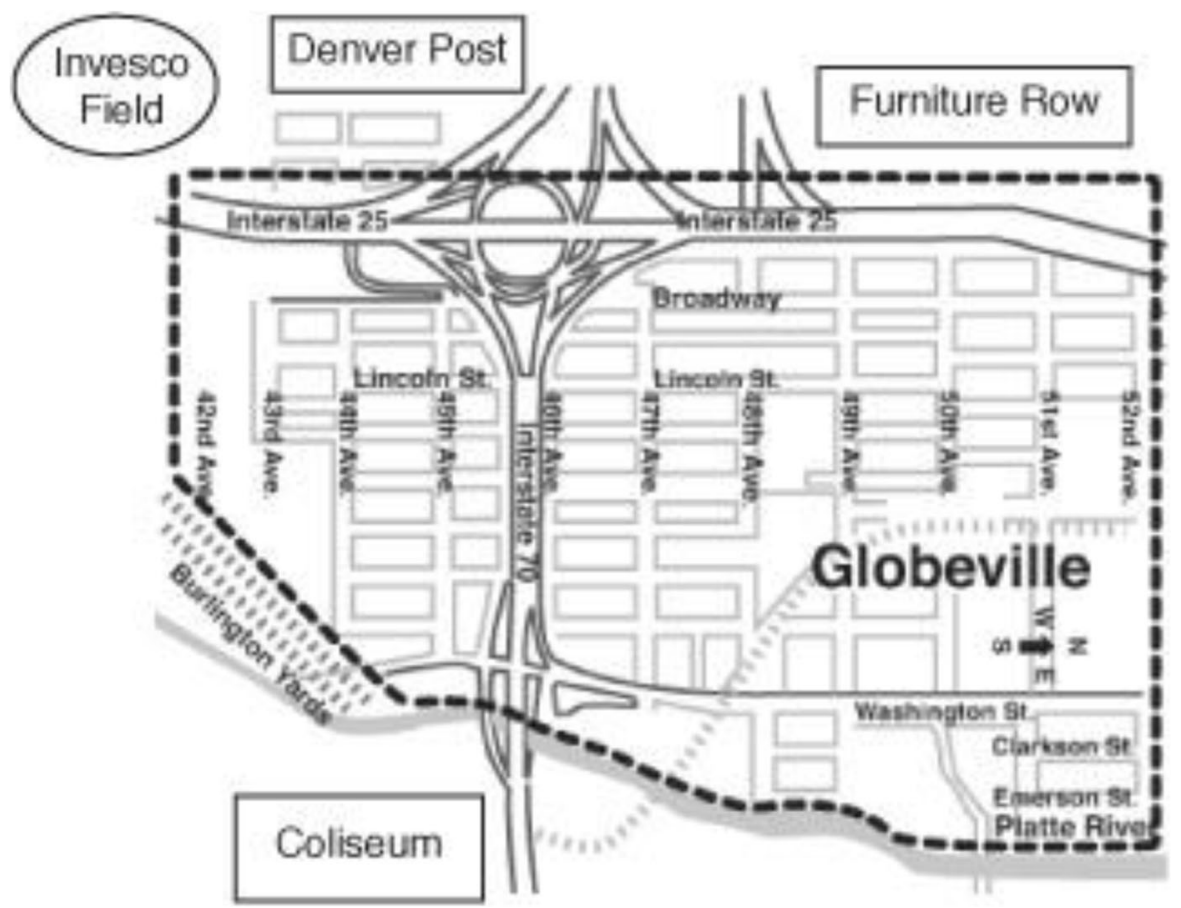

Fig. 1 Map of Globeville (Source: Denver Public Library, 2019) 


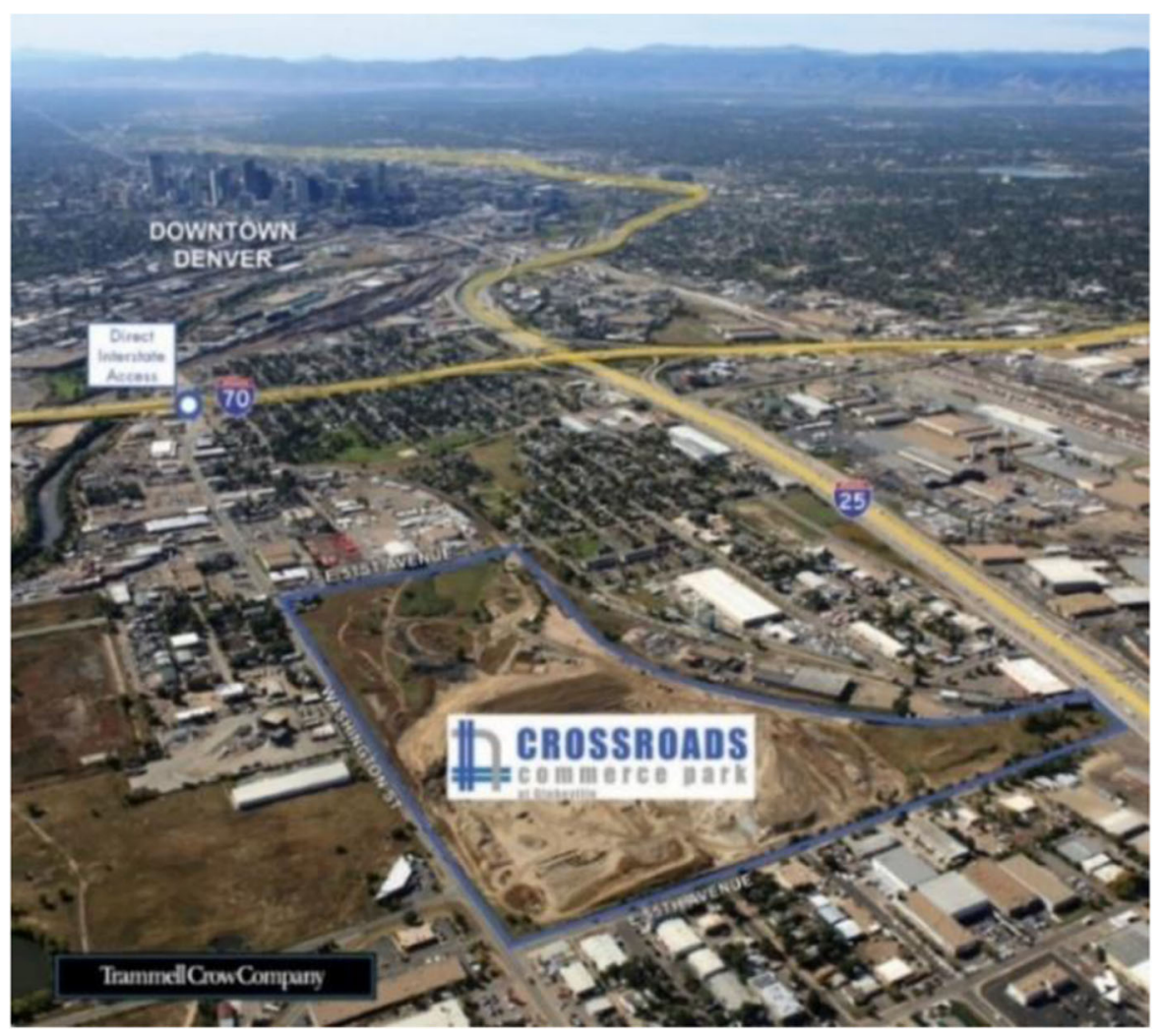

Fig. 2 Globeville, the industrial community Source: Globeville, the Industrial Community, 2016

Globeville became their choice for resettlement because it offered jobs in the smelters, railroads, meat packing plants, foundries, and brickyards. While the homesteaders believed in a lifestyle of self-sufficiency, the smelters favored their lucrative careers, which involved extracting base metals from ores through metallurgical processes. Globeville was a place of great opportunity once upon a time; however, over the years, the demographics of Globeville has changed. I will discuss some of the pertinent changes that Globeville has undergone, and how these changes have impacted the demographics of the area, in later sections of this article.

In 1903, the Omaha and Grant Smelter closed and was gradually dismantled. February 26, 1950 saw the demolition of the Grant Smelter smokestack. This demolition was symbolic of the end of the mining and smelting era, especially for Globeville. For the residents of Globeville, it marked the end of the town's wealth of job opportunities - one of the main reasons for the immigrants to move to Globeville in the first place.

In the late 20s, the Great Depression hit, the stock market crashed. By the 1930s, the effects of the crash were felt greatly by the residents of Globeville. 
Railways cut the road work from 6 days to 2 days per week and meat-packing plants laid off workers. Many Globeville residents lost their jobs and livelihoods. As a result, churches also experienced a drop in membership. Federal programs helped to provide some jobs in areas such as flood control, rat control, and the installation of sanitary sewers.

From 1903 through 1930, progress and assimilation initiatives were put in place in America. Just as Globeville was annexed into the city of Denver, the residents who were initially immigrants into the US were now being offered citizenship. Some assimilation initiatives resulted in the children of immigrants with newly acquired citizenship learning English in American schools. Job opportunities were created in Globeville, and these jobs helped families buy homes and re-settle once again. Small businesses and churches started to prosper.

After World War II, along with the rest of America, the residents in Globeville were once again seeking new jobs. Given the shortage of housing, second generation descendants were seeking new loan opportunities to build houses in the suburbs of Denver. In addition, the Valley Highway and the construction of I-70 split Globeville in half, removing a large number of the original houses in the Globeville area.

The residents: past, present, future

Globeville's story bears a close similarity to that of other immigrant communities such as the Polonia Triangle in Chicago and the North End in Boston. Like all immigrant stories, the story of Globeville starts with people escaping their old countries to pursue the American dream, with the promise of job opportunities or a platform to speak their mind, be that on religion or other issues. Denver holds about one quarter of the state's minority ethnic population, with a total 25,000 immigrants (Abbott et al. 2013), and Globeville holds about a fifth of that immigrant population. In Globeville, which is part of Denver and established in 1889, the Eastern European population fled due to forced army conscription and poverty. These immigrants were hard workers, putting in 12-h days to scrape together a $\$ 2$ daily wage (Doeppers 1967). This first community of immigrants into Globeville bonded together to form fraternal lodges.

Therefore, the large majority of the original residents in Globeville were European immigrants. This section will outline the town's four distinct groups of immigrants. These groups made up the past, some of the present, and perhaps even the future residents of Globeville. The section will continue to highlight two main factors: work opportunities and religious freedom, both of which have brought residents to Globeville.

The Orthodox Slavs, made up of the Carpatho-Russians, came to Globeville for religious freedom and job opportunities. Their religion, which used the people's native Slavic languages instead of Latin at Mass, supported a married clergy. They came in the $1880 \mathrm{~s}$ and worked in the smelters. It was laborious work at the smelters, and workers often fell sick from exhaustion. Support for these men and their families came from the ethnic fraternal lodges. In Globeville, the oldest of these lodges was the Russian Orthodox Catholic Mutual Aid Society, founded in 
1895. In addition to providing insurance and moral support, the goals of these organizations included "the spread and preservation of the Orthodox Faith in America". Members of these lodges also founded the Holy Transfiguration of Christ Cathedral in 1898. As we can see, one of the strongest factors to bring this community together was their religious belief. Their faith also provided comfort when work became too difficult.

Polish immigrants began arriving in Globeville in the 1880s, almost the same time as the Carpatho-Russians. In the beginning, only a small Polish community developed in the 4500-4800 blocks of Washington, Pearl, Pennsylvania, Logan, and Grant Streets, and on Emerson Street near the Platte River. The Polish people in Globeville formed organizations that would provide financial help in the events of injury, sickness, and even death. They formed the St. Joseph's Polish Catholic Church in 1902. They also offered immigrants the comforts of old country customs as they assimilated into the American way of life. The Polish soon moved up the economic ladder as they assimilated and moved out of Globeville to better neighborhoods.

The Southern Slavs, which included the Slovenians, Croatians, Macedonians, and Serbs settled in the southern part of Globeville. Distinguished from the Orthodox Slavs by their Roman Catholic religion and their usage of the Roman alphabet, the groups were easily distinguishable from each other as religion is a strong driving factor for them both. However, like the Orthodox Slavs, Southern Slavs also worked at the smelters, risking disability or even death from the extreme heat, toxic fumes, and dust from the heavy metals. To provide themselves with financial security, the Southern Slavs formed independent, fraternal societies that offered sickness and bereavement benefits for their members. Together with the Russians, they built the Russo-Serbian Orthodox Church of the Transfiguration in 1898. In addition to financial security, these societies also offered a connection to the language, culture, and heritage practices of their members' hometowns. Places like the American Fraternal Union, and the American Slovenian Catholic Union KSKJ, the local Croatian lodge St. Jacob's, and the Western Slavonic Association are among the few clubhouses where the Southern Slavs can feel at home. The Slovenians and Croatians in Globeville also built the Holy Rosary Church at 4664 Pearl Street on July 4th, 1920. The church became a place where the Southern Slavs could attend Mass.

According to Doeppers (1967), although these immigrants viewed themselves as Globeville residents, they still preferred to congregate in smaller neighborhoods with others who shared their cultural heritage and a common language.

The fourth and final group of immigrants who settled in Globeville that I will highlight is the Spanish-speaking people. The Spanish-speaking people who moved to Globeville were not new to Colorado or the US. The Spanish speakers of Globeville moved there for reasons similar to the town's other distinct immigrant groups. Today, they constitute about $82 \%$ of the current population of Globeville, forming one of the largest demographic groups in the area (Source: The Globeville History, 2015). 


\section{Discussion: Spanish-English speaking residents of Globeville - present and future}

As highlighted above, the demographic of Globeville has evolved over the years. In the 1950s, there were only twelve Mexican American households, but by 1965, there were 123. They quickly replaced the Polish as the largest community in Globeville (Doeppers 1967). Currently, the entire neighborhood has become a blend of working and middle-class with a high proportion of Mexican Americans, as well as recent immigrants from Mexico, Central America, and South America (Hunt 1999). Despite the drastic change in the demographic, from having a mixture of Orthodox Slavs, Polish, Southern Slavs, and Spanish-speaking people, to having mostly Spanish-speaking people, one constant remains. Globeville is a neighborhood for immigrants and children of immigrants, and remains a blue collar, working class society, where residents come to find job opportunities and to live near their workplace.

The graph below shows the time taken for the residents of Globeville to travel to work. It can be learned that most of the residents live near their workplace, which is located within the community. This indicates that work opportunities are one of the main reasons why people move to Globeville (Fig. 3).

Based on the above graph, most of the residents in Globeville live and work within the same area. Commute times for the residents in Globeville range between ten and twenty-five minutes. A similar pattern is observed among school-age children, who also attend schools within the Globeville area. The map below shows the schools found in Globeville (Fig. 4).

The current section examines the Spanish-English speaking residents of Globeville, mainly Mexican American bilinguals. Mexican Americans may be a minority in the US, but in Globeville, they are the majority, forming $82 \%$ of the current population (Source: The Globeville History, 2015). Although Globeville is home to a variety of Spanish-speaking residents, this article focuses on the Spanish-

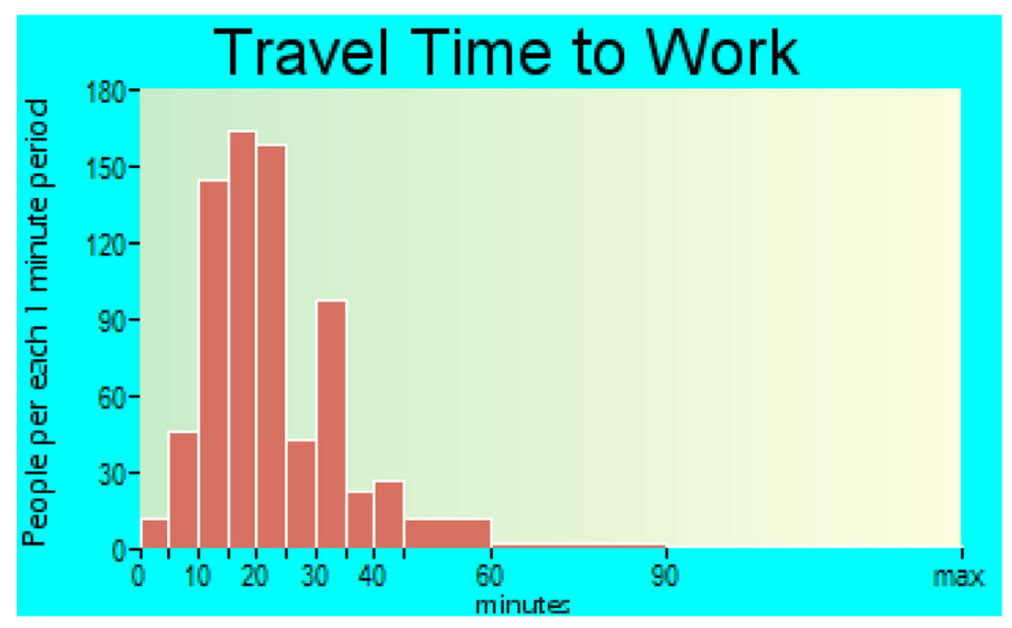

Fig. 3 Residents' Travel Time to Work Source: Citi-data, 2019 


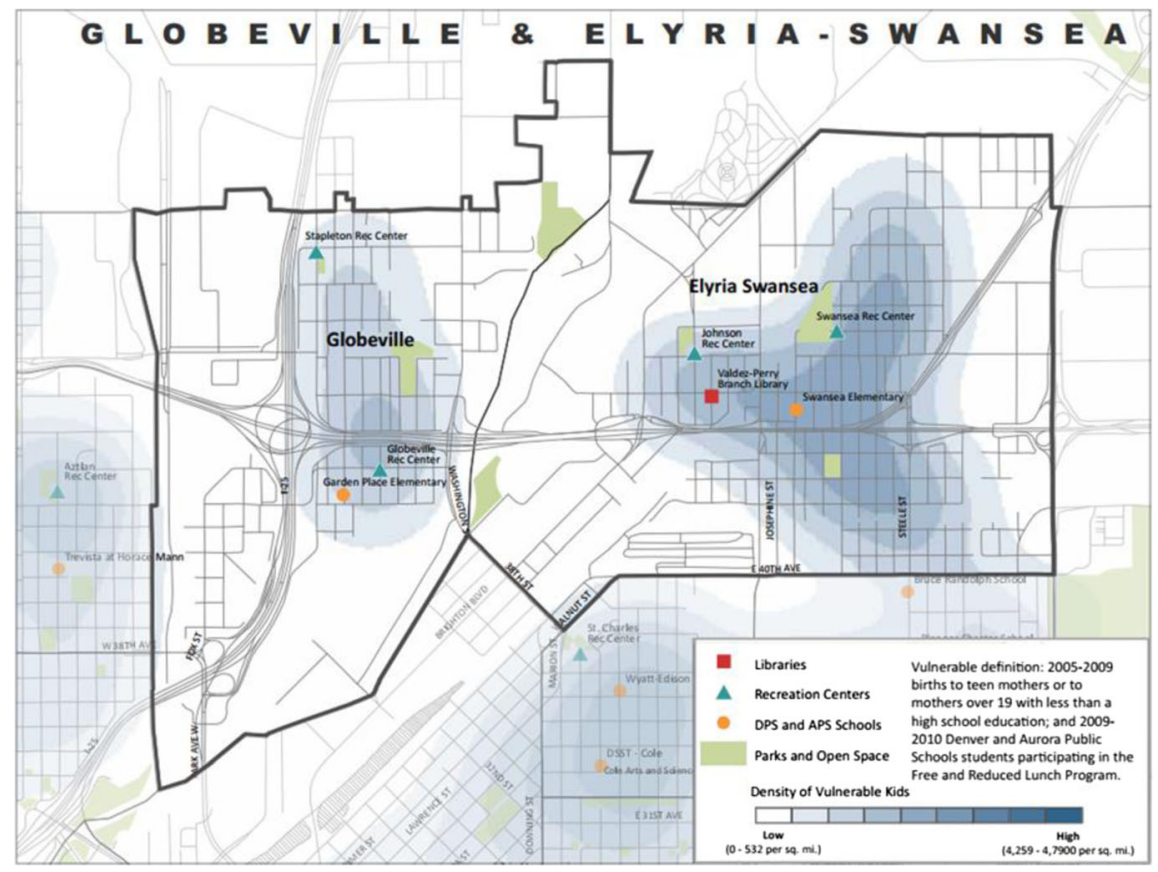

Fig. 4 Schools in Globeville, Source: Floodlight Project, 2019

Fig. 5 Races in Globeville, Source: Citi-data, 2019

\section{Races in Globeville in Denver, CO}

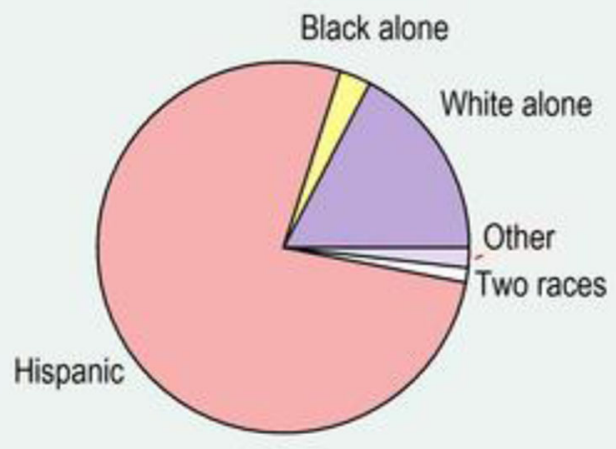


English Mexican American bilinguals living in the area. Due to the dramatic increase in the number and distribution of Mexican American families in the area, it was necessary for Globeville to grow accordingly in size (Fig. 5).

The pie chart below shows the racial demographics of Globeville.

Globeville is home to several groups of immigrants. Immigrants in the US are commonly associated with being of low socio-economic status (SES), having poor proficiency in English, and needing help assimilating into the US. In the US, the majority of immigrants are blue collar, working class individuals. However, being immigrants, one challenge always remains for them, the fear of losing their cultural heritage after leaving their homeland to seek better opportunities. For the residents in Globeville, whose numbers make up fewer than 4000 (Source: Globeville Neighborhood in Denver, 2016), there is a real need to assimilate as Americans (Fig. 6).

The graph above shows a comparison of household incomes conducted by ApartmentGuide. This demonstrates how the average income in Globeville compares with other neighborhoods. Globeville has the lowest average household income in the wider area. Furthermore, in addition to their low SES, the residents of Globeville also have to combat industrial pollution.

\section{Pollution}

The neighborhood, Globeville, is a mixed residential-industrial area. While industrial facilities create job opportunities for the residential community in Globeville,

\section{ApartmentGuide's Comparison of Household Income}

- Neighborhood Avg. Household Income

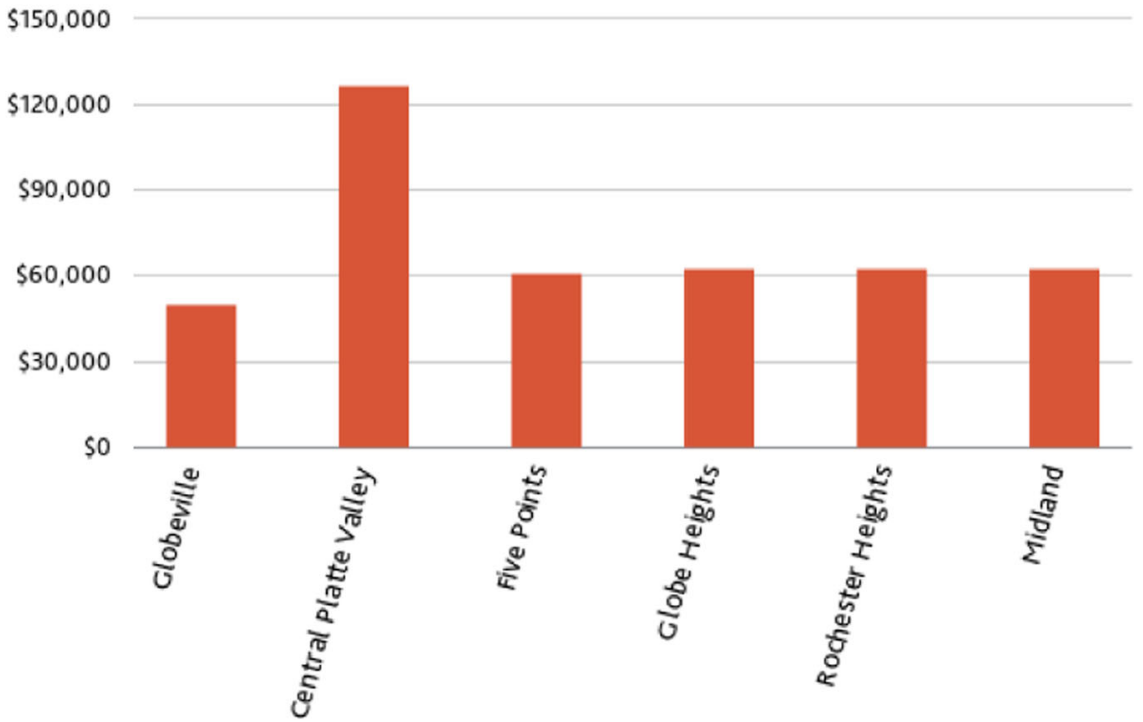

Fig. 6 Household Income in Globeville (Source: Citi-data, 2019) 
the same opportunity results in a very unsettled environment for the neighborhood's residents.

Since the 1980s, the residents in Globeville have been reporting strong industrial odors in the neighborhood that have impacted their lifestyles. The smell of asphalt for one is strong enough to cause eye, nose, and throat irritation. Because of the strong odor, residents are forced to shut their doors and windows, and keep off their yards and patios to avoid discomfort (Morgan et al. 2015). Despite desperate cries to improve the environmental conditions in Globeville, no environmental violation has been reported. This could be partly due to the fact that the pleas come from immigrants into the US, a group of residents that may not be deemed worthy of great investment. However, to resolve the health issues caused by living in the area, sooner or later many residents of Globeville have made the decision to move away (Morgan et al. 2015). This may explain why the demographic has changed so much over time. However, one constant remains, the occupants of Globeville are still immigrants to the US.

The figure below shows the concentration of pollutants, in parts per billion (ppb), present in the atmosphere in Globeville. Despite the high level of pollutants and strong odor that have been recorded, little has been done to improve the situation. The residents of Globeville continue to suffer from constantly high air pollution in the atmosphere (Fig. 7).

\section{Prevalent Compounds in Odor Samples}

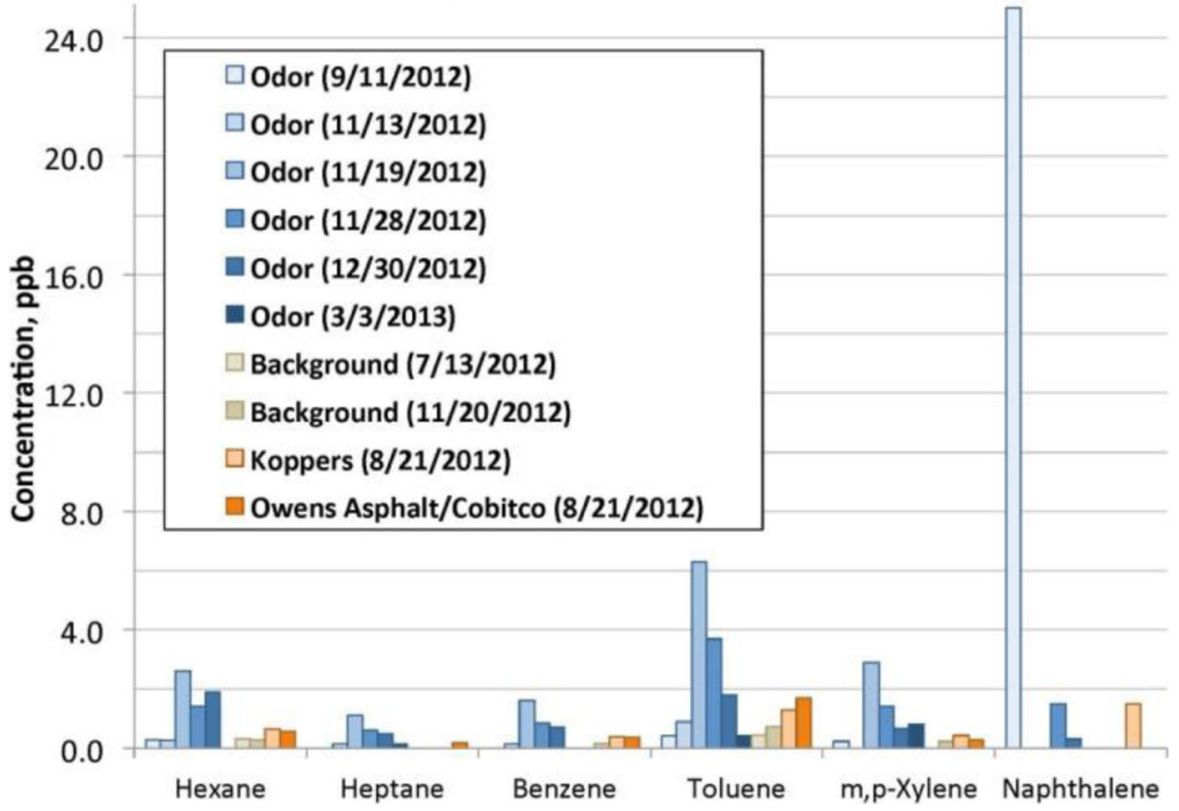

Fig. 7 Recorded air pollutants in Globeville (Morgan et al. 2015) 
The quality of life in Globeville is far from the American dream that once inspired these immigrants to leave their home countries. This is partly because these residents cannot enjoy their own front porches or backyards. Unfortunately, it seems that these events are out of the residents' control.

About a decade ago, in 1994, cleanup workers came to help the residents of Globeville improve the pollution situation. Armed with shovels and diggers, they ripped away sod, flower beds, vegetable gardens, and even sacrificed some of the heirloom roses throughout north Denver in Globeville. They managed to remove twelve to eighteen inches of dirt and soil contaminated with arsenic, cadmium, zinc, and lead that had come from the nearby Ararco plant, where heavy metals had been processed for nearly a century. Despite the residents' worries and pleas, the excavations had done little to solve the unbearable pollution in the area. When the residents continued to complain, the authorities informed them that the soil in Globeville had passed the required quality tests and had been deemed safe; therefore, the residents were to continue living with the situation (Gardner 2014).

Many of these homes in Globeville have low fences around their front porches. In the better-kept part of the Globeville area, there are neat lawns with flowered gardens. This reflects the great care that Globeville residents take in looking after their neighborhood and their homes. There are also areas in which there is a decline in the upkeep of household lawns. These are primarily on the outskirts of the neighborhood, and these areas correlate with the new Mexican American households. However, this correlation is insufficient grounds to draw conclusions about these residents, especially as they are known in the community as responsible tenants who care for their homes and neighborhood (Doeppers 1967). There is not much that they could do to prevent the pollution flowing from the factories into to their backyards.

Besides not having access to clean air in the Globeville neighborhood, the residents also do not have access to fresh food produce.

\section{Food deserts}

A "food desert" is defined as an urban area in which the population does not have access to healthy, fresh foods. Sadly, food deserts in Denver only occur in areas populated by low-income, minority communities (Stilley 2012). Food deserts can also refer to an area where low-income minority residents do not have access to healthy and affordable foods, and where fast food restaurants dominate the landscape (Gordon et al. 2011). The first use of the term "food deserts" in North America referred to a rural area of the Missisippi that lacked supermarket access (Rose et al. 2009). Since then, research on food deserts has expanded greatly in the US. In this study, Globeville is the focus area for a discussion on food deserts.

Food deserts create numerous problems for the local population. Although food deserts refer to an inaccessibility of fresh foods, the absence or lack of fresh foods have negative implications. Food deserts also have a correlation with negative health conditions (Raja et al. 2008). Without access to fresh foods on a regular basis, one can risk developing type 2 diabetes or other diet-related health problems (Meade 2008). Food deserts also cause environmental justice problems. Here, the phrase 
"environmental justice problem" is defined as "the fair treatment and meaningful involvement of all people regardless of race, color, national origin, or income with respect to the development, implementation, and enforcement of environmental laws, regulations, and policies" (U.S. Environmental Protection Agency 2012).

A study conducted by Stilley (2012) who looked at 9 focus neighborhoods in the County of Denver, identified two of the studied areas, Elyria Swansea and Globeville, as food deserts. The study also revealed that these areas have a high proportion of children and a very high percentage of new birth rates. This shows the pressing need to improve access to fresh, healthy food in these areas, as childhood development is a growing concern in the United States. As mentioned above, Globeville has a large Hispanic population. The Colorado Department of Public Health and Environment (2015) has highlighted that the two races that are most likely to develop diabetes are Blacks and Hispanics. This is especially true among Coloradoan adults aged 45-64 years old. Therefore, Globeville and its neighbor, Elyria Swansea, are areas in real need of better access to fresh, healthy foods in order to help the residents combat diabetes and other diet-related health issues.

Residents of Globeville and Elyria Swansea have very limited options in terms of grocery stores that are within walking distance, or connected to bus links. Due to widespread air and soil pollution, home-growing fresh crops in backyards is not an option for the residents of these areas. Therefore, residents are not only suffering from polluted air, which is damaging the soil in their backyards, they are also living in a food desert, which can lead to more health issues in the future. Alongside these issues, residents also have to deal with the noise pollution caused by highway construction, which continues to marginalize them.

\section{Construction of highways}

Besides air pollution, soil pollution, and daunting health issues caused by food desert conditions, noise pollution is yet another challenge for the residents of Globeville to contend with. Currently, the noise from traffic on I-25 and I-70 rumbles through the neighborhood. The reconstruction of highway, I-70, will not only add to the existing air pollution in the area, it is also contributing to the existing noise pollution affecting the residents of Globeville.

At 50 years old, the town's viaduct is deteriorating. This testifies to the need for growth and redevelopment in an area bound to the east and south by the South Platte River, Inca Street to the west, and the city limits to the north, around 53rd Avenue. According to Mayor Michael Hancock, development is much needed to reconnect Globeville and Elyria-Swansea to a better future; a future "with a coordinated push on six key projects". He has promised that the reconstruction will help to: improve the health of the South Platte River; turn Brighton Boulevard into an inviting gateway to Downtown; reconstruct I-70 so that the neighborhoods and businesses will be reconnected; provide more accessibility to commuters with light rail stations, and implement neighborhood revitalization programs.

Local historian, Mary Lou Egan explained that the residents of Globeville have expressed doubts over the rationales behind the prospective projects. This doubt arises from years of exploitation through generations of poor urban planning and 
hostile treatment dealt upon the residents of Globeville, past and present. The residents of Globeville do not want to be viewed as living on a piece of land that is underdeveloped. They are proud of their neighborhood, which has been home to generations of families, homes, places of worship, and a rich local history. In the words of Mary Lou Egan, Globeville has personality.

In the past, the construction of I-25, which started in 1948, forced residents to be relocated and their homes destroyed. Soon after, the construction of I-70 followed suit. The route for I-70 marched past Pomponio's Restaurant, a shopping center, and a Buddy's Truck Stop. The point at which the two highways were to meet stood at the heart of Globeville, causing immense upheaval for its residents. Those who found themselves in the path of construction were forced to evacuate. Buildings were split in half when owners refused to move, yet these owners were still expected to pay property tax on the whole plot and not the half that they could reside in. St. Joseph Polish Church and its school barely survived. In 1984, a semi-trailer carrying Navy torpedoes flipped over on one of the intersection's curves. Since then, over twenty construction projects have taken place, closing exits, rebuilding ramps, adding bridges, and further cutting off access routes in and out of Globeville for its residents.

Over the years, the residents at Globeville have had to deal with noise, pollution, and isolation. Gradually, the residents moved away, and the demographic changed.

Public library?

On top of having to battle with physical challenges such as pollution (air, soil, and noise) and enduring inaccessibility to fresh and healthy food produce, the residents of Globeville also have to overcome a considerable intellectual obstacle. For years now, the residents of Globeville been deprived of access to a proper public library.

Globeville and its two neighbors, Eyria and Swansea, have not had a branch library since the 1950s (Sarling and Van Tassel 1999). Bookmobiles that visit the local elementary schools in these areas, such as Swansea Elementary, is the only form of library services to reach the community. During one of the days that I was at Swansea Elementary School, I was fortunate to have observed the bookmobile visit where the students were each given a book to take home and read. The students were excited about the books they had selected; they enjoyed showing me their books and the kindergarteners sat me down to read for them. From my observations, it was apparent that the children enjoyed reading, if given access to books; however, such privilege has been denied to them.

Inaccessibility to a public library has greatly affected the residents in Globeville. In 1990, the US Census Data reported that North Central Denver has a concerning percentage of teenage dropouts, 29.93\%. This is the highest in Denver County, standing at $16.17 \%$, and Colorado, at $9.77 \%$. The census also reported that unemployment in the North Central Denver area was double that of anywhere else in the state. On these grounds, it is safe to conclude that the absence of a public library, combined with other direct or indirect factors, has adversely affected the educational experience of residents, leading to issues around unemployment and income. 


\section{Conclusion}

How does the community, through its geographical location, contribute to the development, or lack thereof, of marginalized BFLA Spanish-English Mexican American bilinguals? For years now, the residents in Globeville and its immediate neighboring areas, Swansea and Elyria have been separated from the rest of Colorado. They have not been given adequate access to some of the most basic needs such as free and public education in the form of a public library, and fresh and healthy food. Instead, they have been given an oversupply of air, soil, and noise pollution. The current residents who are mostly Hispanics have come together to voice their thoughts, to fight back to defend what is left of their homes.

\section{Voices of the residents}

With all that has happened to Globeville, the residents decided to fight back. In 1972 they thought they had won the battle, when the city's Study for the Community Renewal Program concluded, "Globeville should remain residential in the areas that are at present residential." Unfortunately, that was a lie. The idea of turning Globeville into an industrial park was risen again in 1975. It took the residents another 2 years of negotiations to stop the city from re-zoning Globeville as an industrial park. However, in 2006, the city council remodeled its original zoning code, and Globeville slowly slipped into neglect. The residents were also refused home improvement loans (Gardner 2014).

Today, through social media platforms, the residents in Globeville have finally been given a voice. Facebook, a popular social media platform is one way through which the residents of Globeville voice their views. On this site, visitors can not only observe the goings-on in the neighborhood, they can also make themselves aware of local activities and celebrations. The residents also use schools as an additional platform to inform others to come forth and make a stand. Flyers are placed at schools to act as a medium of communication among the residents of Globeville. (see image below) (Fig. 8).

In a neighborhood that has begun to distrust the government, residents need time to recover. The mayor's 2015 project has pledged $\$ 47$ million for projects in the area. However, much of that will go towards the Brighton Boulevard project. Perhaps Globeville might enjoy part of that budget. For now, residents have gained a voice to try and fight back, through various means and channels including education.

How does the community, through its geographical location, contribute to the development, or lack thereof, of marginalized BFLA Spanish-English Mexican American bilinguals? Based on Bronfenbrenner's theory of the ecology of human development, I focused on Globeville, as the central setting of the qualitative study, in order to look at how the setting and community have helped or impeded the development of marginalized BFLA Spanish-English Mexican American bilinguals.

I looked at the historiography of Globeville, highlighting some of the pertinent events that have impacted Globeville over the years. In addition, I traced the 


\section{I-70 East Project Office}

Located at

\section{East 46th Avenue}

(inside the Denver Rescue Mission)

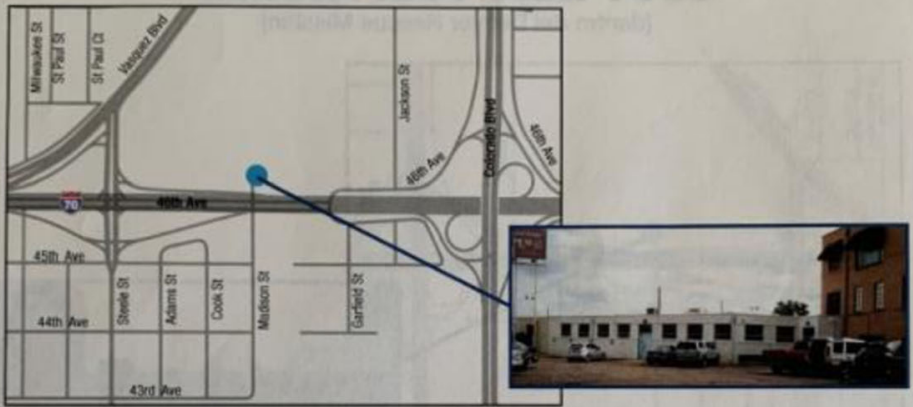

Spanish interpreters and project staff will be available during office hours to answer questions on the project, help residents study the Supplemental Draft EIS, get their questions answered, and collect formal comments.

Office hours are:

10:00 a.m. to 7:00 p.m., Monday through Thursday 9:00 a.m. to $12: 00$ p.m., Friday and Saturday

www.i-70east.com 303-313-2420

The 170 East Project Office is not accessible under the Americans with Disabilities Act. For disability arsistance please call 303-313-2420 in order for CDOT to arrange other accommodations Dial 711 to use Relay Colorado (TT)
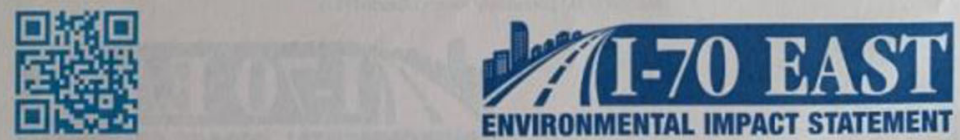

Fig. 8 Globeville's personal communication (source: author's photograph)

original residents and how the demographic has evolved over the years. Interestingly, one constant remained. Globeville belongs to immigrants who are there to seek the American dream of better job opportunities, religious freedom, and a voice to speak their mind. Are these immigrants achieving their American dreams in Globeville? How has Globeville evolved to help them achieve these dreams? 
As highlighted above, the residents faced a medley of challenges living in Globeville. Some of these challenges are still prevalent and on-going. They include restricted access to basic needs such as clean air and fresh produce. While these needs are easily taken for granted in more privileged areas, the residents of Globeville have had to fight long and hard for these needs.

In addition to their inaccessibility to basic needs, residents were also deprived of a public library. They were, however, still held to the same academic standards in school as students living in better provisioned neighborhoods. Despite these challenges, the community of BFLA Spanish-English Mexican Americans continue to work to better their situation. In a larger study, these student-participants demonstrated bilingual abilities at school. On average, they were working to the expected standard, with the younger learners performing above standard expectations.

One major difference between today and several decades ago is that, the residents of Globeville now have the opportunity to speak their mind. Perhaps the current residents, Mexican Americans (BFLA Spanish-English children included), will have the means to defend Globeville for generations to come. Meanwhile, they can work to make it a less polluted, less industrial, and more residential neighborhood, a better learning environment for immigrant children to flourish despite the odds against them.

\section{Publisher's Note}

Springer Nature remains neutral with regard to jurisdictional claims in published maps and institutional affiliations.

Acknowledgements I would like to thank my mentor, Dr. Sheila Shannon from the University of Colorado, for her valuable feedback.

\section{Authors' contributions}

Sole authorship. The author read and approved the final manuscript.

\section{Funding}

Not applicable.

\section{Availability of data and materials}

Refer to citations and reference page. 


\section{Ethics approval and consent to participate}

Not applicable.

\section{Consent for publication}

Not applicable.

\section{Competing interests}

The author declares that she has no competing interests.

\section{References}

Abbott, C., S.J. Leonard, and T.J. Noel. 2013. Colorado: A history of the centennial state. 5th ed. Boulder: University of Colorado.

Bronfenbrenner.U. 1979. The ecology of human development: Experiments by nature and design. Massachusetts: Harvard University Press.

Brown, D. 2007. Principles of language learning and teaching. 5th ed. White Plains: Pearson Longman.

Census. (2010). Retrieved from http://www.census.gov/newsroom/releases/archieves/foreignborn_population/ cb10-159.html. Accessed 2019.

Citi-data. (2019). Retrieved from http://www.city-data.com/. Accessed 2019.

Colorado Department of Public Health and Environment. (2015). https://www.colorado.gov/cdphe. Accessed 2019.

Creswell, J.W. 2013. Qualitative Inquiry \& Research Design: Choosing among five approaches. 3rd ed. Thousand Oaks: Sage.

Cummins, J., and M. Danesi. 1990. Heritage languages: The development and denial of Canada's linguistic resources. Montreal: Our Selves Education Foundation.

Demont-Heinrich. 2007. The ideological construction of the juggernaut of English: A critical analysis of American prestige press coverage of the globalization of language. Studies in Language and Capitalism 1 (2): 119-144.

Denver Public Library. (2019). Retrieved from https://www.colorado.gov/cdphe. Accessed 2019.

Doeppers, D.F. 1967. The Globeville neighborhood in Denver. Geographical Review 57 (4): 506-522.

Fay, B. 1987. Critical social science. Ithaca: Cornell University Press.

Fisher-Ari, T.R., K.M. Kavanagh, and A. Martin. 2017. Sisyphean neoliberal reforms: The intractable mythology of student growth and achievement master narratives within testing and TFA era. Journal of Education Policy 32 (3): 255-280.

Flanagan, J.C. 1954. The critical incident technique. Psychological Bulletin 51 (4): 327-358.

Floodlight Project. (2019). Retrieved from http://www.projectfloodlight.org/. Accessed 2019.

Gardner, N. (2014). Welcome to Globeville. 5280.com. Nov. 87-202.

Globeville Neighborhood in Denver. (2016). Retrieved from http://www.city-data.com/neighborhood/Globeville-Denver-CO.html. Accessed 2019.

Globeville, the Industrial Community. (2016). Retrieved from http://denverrealestatewatch.com. Accessed 2019.

Gordon, C., M. Purciel-Hill, N.R. Ghail, L. Kaufman, R. Graham, and G. Van Wye. 2011. Measuring food deserts in New York's low-income neighborhoods. Health \& Place 17: 696-700.

Hunt, R.A. 1999. Urban pioneers: Continuity and change in the ethnic communities in two Denver, Colorado neighborhoods: 1875-1998. Colorado: University of Colorado.

Meade, M.N. 2008. The sprawl of food deserts. Environmental Health Perspectives 11 (8): A335. 
Morgan, B., R. Hansgen, W. Hawthorne, and S. Miller. 2015. Industrial odor sources and air pollutant concentrations in Globeville, a Denver, Colorado Neighborhood. Journal of the Air \& Waste Management Association 65 (9): 1127-1140.

Nalls, I. 2019. BFLA Spanish-English Mexican American bilinguals. Critical Inquiry in Language Studies 16 (1): 30-49. https://doi.org/10.1080/15427587.2018.1520598.

National Center for Education Statistics. 2016. Racial/ethnic enrollment in public schools. Washington, DC: U.S. Department of Education Retrieved from http://nces.ed.gov/programs/coe/indicator_cge.asp.

Orfield, G., and C. Lee. 2005. Why segregation matters: Poverty and educational inequality, 1017 E-resource: http://www.civilrightsproject.ucla.edu/research/deseg/Why_Segreg_Matters.pdf.

Raja, S., C. Ma, and P. Yadav. 2008. Beyond food deserts: Measuring and mapping racial disparities in neighborhood food environments. Journal of Planning Education and Research 27: 469-482.

Rose, D.D., J.N. Bodor, C.M. Swalm, J.C. Rice, T.A. Farley, and P.L. Hutchison. 2009. Deserts in New Orleans? Illustrations of urban food access and implications for policy. Ann Arbor, MI: Paper prepared for the University of Michigan National Poverty Center and the USDA Economic Research Service Center.

Sarling, J.H., and D.S. Van Tassel. 1999. Community analysis: Research that matters to a north-Central Denver community. Library \& Information Science Research 21 (1): 7-29.

Shannon, S.M. 1995. The hegemony of English: A case study of one bilingual classroom as a site of resistance. Linguistics and Education 7: 175-200.

Stilley, M. 2012. Urban food deserts: An exploration of northern neighborhood in Denver. Colorado: University of Colorado.

The Globeville History. (2015). Retrieved from http://globevillehistory.com

U.S. Environmental Protection Agency. (2012). Environmental Justice. Retrieved from http://www.epa.gov/ environmentaljustice/. 